\title{
Metabolic syndrome in children and adolescents - criteria for diagnosis
} Marcio C Mancini

Address: Group of Obesity and Metabolic Syndrome, Endocrinology \& Metabolism Service, Faculty of Medicine, University of Sao Paulo, Sao Paulo, Brazil

Email: Marcio C Mancini - mmancini@usp.br

Published: 19 October 2009

Diabetology \& Metabolic Syndrome 2009, I:20 doi:10.1186/1758-5996-1-20

This article is available from: http://www.dmsjournal.com/content/l/I/20

(C) 2009 Mancini; licensee BioMed Central Ltd.

This is an Open Access article distributed under the terms of the Creative Commons Attribution License (http://creativecommons.org/licenses/by/2.0), which permits unrestricted use, distribution, and reproduction in any medium, provided the original work is properly cited.
Received: 2 April 2009

Accepted: 19 October 2009

\begin{abstract}
In recent years, there has been a greater concern about the presence of obesity and metabolic syndrome in children and adolescents. However, there is no consensus regarding the diagnosis of metabolic syndrome in children and adolescents. It is evident that each component of the syndrome must be identified as early as possible in order to prevent definitive lesions. The question is how to do this and which cut-offs must be adopted for this diagnosis. For a matter of convenience, the definition chosen as the most appropriate is the one proposed by the IDF, with cut-offs fixed for pressure, lipids and glycemia, and abdominal circumference points assessed by percentile. Although on the one hand this definition could fail to include some children in the diagnosis of Metabolic Syndrome, on the other hand, it would be of easier acceptance as it does not use multiple tables to assess several anthropometric and metabolic criteria.
\end{abstract}

\section{Introduction}

We are presently going through a paradox in Brazil expressed by a decrease in infantile malnutrition from $16 \%$ in 1974 to $4.6 \%$ in 2003 with a gradual increase in obesity, which today occurs in $18 \%$ of boys and $15 \%$ of girls, according to the Family Budget Research (POF 20022003). It is widely known that obesity has been increasing over time and Brazilian data on malnutrition shows that it is decreasing significantly, whereas obesity has been increasing in an opposite way. Nowadays, $18 \%$ of boys and $15 \%$ of girls are obese[1].

The Bogalusa study, which assessed 66 children autopsies from six years old on with known cardiovascular risk factors, observed that the total cholesterol level and the blood pressure of these children were proportional to the infiltration of foam cells and to the amount of lipids in the arterial intimate layer. Lesions were gradual, evolving from the simple presence of fatty stretch marks to lesions of fibrous plaques and finally to severe lesions characterized by atherosclerotic plaques with fibrosis and necrosis, which have already been observed in children [2].

Evidently, this leads to losing years of life. If the individual's BMI indicates they are overweight from 20 years old on, this would result in losing one year of life in the long term. If we consider the effect of presenting morbid obesity since 20 years of age, this would result in losing 12 years of life in the long term. The later the development of overweight or obesity, fewer are the years of life lost [3]. Therefore, we may infer that it is important for us to treat obesity and metabolic syndrome since childhood.

Several large epidemiologic cohort studies (such as Framingham Offspring Study, Botnia Study, Kuopio Ischemic Heart Disease Study, NHANES II Mortality Study, San 
Antonio Heart Study and DECODE Study) have documented that metabolic syndrome is associated with cardiovascular outcomes in adults, such as infarction, cerebrovascular disease and sudden death [4]. In recent years, there has been a greater concern about the presence of obesity and metabolic syndrome in children and adolescents. It was demonstrated in 2004 that the prevalence of metabolic syndrome increases as it evolves from a lower tertile to a higher tertile of insulin resistance. This has been observed in different ethnical groups (Caucasians, Hispanics and Blacks), and in different obesity degrees (moderately obese and severely obese individuals). It has also been demonstrated that there is a direct association between insulin resistance tertiles and C-reactive protein, and inverse association with adiponectin levels [5].

\section{Metabolic Syndrome Diagnosis in Children and Adolescents}

There is no consensus regarding the diagnosis of metabolic syndrome in children and adolescents. It is evident that each component of the syndrome must be identified as early as possible in order to prevent definitive lesions. The question is how to do this and which cut-offs must be adopted for this diagnosis.

The diagnosis of metabolic syndrome in children and adolescents requires the assessment of the abdominal circumference (or BMI), pressure, lipoproteins and glycemia. There is even controversy about how to measure the abdominal circumference in adults; measure points differ. Thus, there are proposals: one of them was published in 1999 by Freedman, which is one of the authors of the Bogalusa study [6]. In this article, the authors have correlated the $90^{\text {th }}$ percentile of abdominal circumference with increased levels of LDL cholesterol, glycemia, insulin and diminished HDL levels. Limits were established and the use of a chart for abdominal circumference was proposed (over the $90^{\text {th }}$ percentile, considered to be the maximum normal limit).

By the other hand, Taylor proposed different values. He compared abdominal circumference with abdominal fat measured by densitometry [7]. The possible criticism is that, depending on the age range, the number of children analyzed was very low.

Some people claim that the metabolic syndrome in children must be defined by BMI and not by the abdominal circumference. An adjusted BMI curve according to gender and age was proposed to the Brazilian population, elaborated by the group of Prof. Carlos Monteiro from the Public Health School of University of Sao Paulo (USP) [8]. Despite the existence of this curve even for the matter of comparing studies, BMI curves adjusted by the NorthAmerican CDC have been more widely used. The normal BMI varies according to the child's age. Thus, it is impossible to apply a BMI range of 18.5-24.9 to a 12 or 13-yearold child. Overweight is defined from $85^{\text {th }}$ percentile and obesity from $95^{\text {th }}$ percentile [9] (Charts are available at http://www.cdc.gov).

Regarding blood pressure, tables must also be used. Additionally, the inflatable cuff width must be at least $40 \%$ of the arm circumference and its length must be at least $80 \%$ of the distance between the elbow and the acromion. In practice, it is not necessary to constantly measure the distance, but one must certify that the sleeve occupies most of the arm length circumference. It is recommended to verify the blood pressure of all children from 3 years old on and of children under 3 in case they have associated risk factors [10]

(Charts are available at http://www.nhlbi.nih.gov/guide lines/hypertension/child tbl.htm).

Regarding lipoproteins, a recent document of the American Academy of Pediatrics establishes the percentiles of total cholesterol, triglycerides, LDL and HDL for boys and girls of several age ranges. Regarding lipoproteins, below the $75^{\text {th }}$ percentile is considered acceptable, corresponding to total cholesterol below $170 \mathrm{mg} / \mathrm{dL}$ and LDL below $110 \mathrm{mg} / \mathrm{dL}$. Between $75^{\text {th }}$ and $95^{\text {th }}$ percentile considered borderline and elevated is over $95^{\text {th }}$ percentile. Pharmacological treatment is indicated in the following cases: if risk factors with LDL persistently over $190 \mathrm{mg} / \mathrm{dL}$ are not

Table I: Proposals for rating the metabolic syndrome in children and adolescents

\begin{tabular}{llll}
\hline & Cook et al. & De Ferranti et al. & Weiss et al. \\
\hline & 3 or more among the $\mathbf{5}$ criteria below & \\
\hline Adiposity: abdominal circumference (AC) or BMI & $A C \geq p$ 90th & $A C>p$ 75th & BMI z score $\geq 2,0$ \\
Fasting glycemia or at OGTT (mg/dL) & Fasting gly $\geq 110$ & Fasting gly $\geq 110$ & Glycemia at OGTT of I40-200 \\
Blood pressure & $\geq p 90$ th & $>p 90$ th & $>p$ 95th \\
HDL Cholesterol $(\mathrm{mg} / \mathrm{dL})$ & $\leq 40$ & $<50$ (girls) e $<45$ (boys) & $<\mathrm{p}$ th \\
Triglycerides $(\mathrm{mg} / \mathrm{dL})$ & $\geq 110$ & $\geq 100$ & $>p 95$ th
\end{tabular}


Table 2: IDF proposal for metabolic syndrome definition in children and adolescents

\begin{tabular}{|c|c|c|c|}
\hline \multirow[t]{2}{*}{ Criteria/components } & \multicolumn{3}{|c|}{ Age } \\
\hline & 6 to $<10$ years-old & 10 to 16 years-old & $>16$ years-old \\
\hline Adiposity definition & WC $\geq 90^{\text {th }}$ percentile & $W C \geq 90^{\text {th }}$ percentile & $W C \geq 90 \mathrm{~cm}$ (boys) or $\geq 80 \mathrm{~cm}$ (girls) \\
\hline Glucose metabolism & $\begin{array}{l}\text { Without cut-off definition for MS } \\
\text { diagnosis }\end{array}$ & Fasting blood glucose $\geq 100 \mathrm{mg} / \mathrm{dl}$ & Fasting blood glucose $\geq 100 \mathrm{mg} / \mathrm{dl}$ \\
\hline Dyslipidemia & $\begin{array}{l}\text { Without cut-off definition for MS } \\
\text { diagnosis }\end{array}$ & $\begin{array}{l}\mathrm{Tg} \geq 150 \mathrm{mg} / \mathrm{dl} \text { or } \mathrm{HDL}-\mathrm{ch} \geq 40 \mathrm{mg} / \mathrm{dl} \\
\text { or taking LLD }\end{array}$ & $\begin{array}{l}\mathrm{Tg} \geq 150 \mathrm{mg} / \mathrm{dl} \text { or HDL-ch } \geq 40 \text { (boys) or } \\
\geq 50 \mathrm{mg} / \mathrm{dl} \text { (girls) or taking LLD }\end{array}$ \\
\hline Arterial hypertension & $\begin{array}{l}\text { Without cut-off definition for MS } \\
\text { diagnosis }\end{array}$ & $\begin{array}{l}\mathrm{DBP} \geq 130 \text { or } \mathrm{SBP} \geq 85 \mathrm{mmHg} \text { or } \\
\text { taking } \mathrm{AHD}\end{array}$ & $\begin{array}{l}\mathrm{DBP} \geq 130 \text { or } \mathrm{SBP} \geq 85 \mathrm{mmHg} \text { or taking } \\
\mathrm{AHD}\end{array}$ \\
\hline
\end{tabular}

WC: waist circumference; MS: metabolic syndrome; Tg: triglyceride levels; HDL-ch: HDL-cholesterol levels; LLD: lipid-lowering drug; DBP: diastolic blood pressure; SBP: systolic blood pressure; AHD: antihypertensive drug.

present; if there is any risk factor such as obesity, hypertension or smoking and LDL over $160 \mathrm{mg} / \mathrm{dL}$; and diabetic patients with LDL over $130 \mathrm{mg} / \mathrm{dL}$ [11].

Regarding fasting glucose levels, values considered for children and for adults were the same.

\section{Proposals of Definition of Metabolic Syndrome in Children and Adolescents}

The first proposal of definition was published in 2003. It was elaborated by assessing adolescents from 12 to 19 years old using modified criteria, based on the criteria of NCEP/ATP-III, including abdominal circumference over percentile 90, blood pressure over the limits established by the National Blood Pressure Education Program, lipids over the limits established by the National Cholesterol Education Program for children, and glycemia over the values for adults. The general prevalence found in this population of 12-19 years old patients was $4.2 \%$, and when only obese patients over the percentile 95 were considered, the prevalence was $28.7 \%$ [12].

The second proposal of definition is very similar to the previous one, but the cut offs were inferior regarding abdominal circumference and lipid profile. Thus, prevalence is higher (when considering patients with BMI percentile adjusted over the percentile 85, it was 31\%) [13].

The third proposal chose BMI to serve as a base, justifying that it would be less dependent on ethnical variations - we are aware that abdominal circumference may vary according to the race. The prevalence in moderately obese patients (considering those who had $Z$ of 2 and 2.5) was $38.7 \%$, and in severe obese patients (with $Z$ over 2.5 of pattern deviations), it was $49.7 \%$ [14] (Table 1).

Finally, the definition we believe is most appropriate and which was added to this SBD publication is the one proposed by the IDF. It divided children into age groups. There was not a well defined proposal for children under
6 years of age, due to the lack of data. Differently from the criteria presented above, in this proposal, for a matter of convenience, the cut-offs were fixed for pressure, lipids and glycemia, and abdominal circumference points were assessed by percentile. In children aged 6-10, the cut-offs of metabolic and blood pressure variables were not well defined, assessing simply adiposity (considering abdominal circumference over the $90^{\text {th }}$ percentile). The same criteria would be used for children aged 10-16; regarding glycemic metabolism, fasting glycemia $\geq 100 \mathrm{mg} / \mathrm{dL}$, triglycerides $\geq 150 \mathrm{mg} / \mathrm{dL}$, HDL cholesterol below $40 \mathrm{mg} / \mathrm{dL}$ or using a hypolipemiant drug, and blood pressure limits $\geq 130$ or $\geq 85 \mathrm{mmHg}$ or using a antihypertensive drug. If the patient had altered abdominal circumference and two more factors, the metabolic syndrome diagnosis would be established. The difference is that, for adolescents over 16 years of age, there is a differentiation between HDL $\leq 40$ for men and $\leq 50$ for women (Table 2) [15].

Thus, discussions and doubts exist about which criterion to use. Evidently, the IDF criterion, though more convenient, could fail to include some children in the diagnosis of Metabolic Syndrome. On the other hand, it would be of easier acceptance as it does not use multiple tables to assess several anthropometric and metabolic criteria.

\section{Competing interests}

The author declares that he does not have any competing interests regarding the scope of this review.

\section{Authors' contributions}

MCM conceived of the review, including the design and coordination of the text.

\section{Acknowledgements}

The author would like to thank Marilia de Brito Gomes and Daniel GianellaNeto for providing technical help and assistance.

\section{References}

I. IBGE: Instituto Brasileiro de Geografia e Estatística. [http:// www.ibge.gov.br]. 
2. Tracy RE, Newman WP, Wattigney WA, Srinivasan SR, Strong JP, Berenson GS: Histologic features of atherosclerosis and hypertension from autopsies of young individuals in a defined geographic population: the Bogalusa Heart Study. Atherosclerosis 1995, I16:163-79.

3. Fontaine KR, Redden DT, Wang C, Westfall AO, Allison DB: Years of life lost due to obesity. JAMA 2003:289.

4. Halpern A, Mancini MC: Treatment of obesity: an update on anti-obesity medications. Obes $\operatorname{Rev} 2003,4: 25-42$.

5. Weiss R, Dziura J, Burgert TS, Tamborlane WV, Taksali SE, Yeckel CW, Allen K, Lopes M, Maviye M, Morrison J, Sherwin RS, Caprio S: Obesity and the metabolic syndrome in children and adolescents. N Engl J Med 2004, 350:2362-74.

6. Freedman DS, Serdula MK, Srinivasan SR, Berenson GS: Relation of circumferences and skinfold thicknesses to lipid and insulin concentrations in children and adolescents: The Bogalusa Heart Study. Am J Clin Nutr 1999, 69:308-17.

7. Taylor RW, Jones IE, Williams SM, Goulding A: Evaluation of waist circumference, waist-to-hip ratio, and the conicity index as screening tools for high trunk fat mass, as measured by dualenergy X-ray absorptiometry, in children aged 319 y. Am J Clin Nutr 2000, 72:490-5.

8. Conde WL, Monteiro CA: Body mass index cutoff points for evaluation of nutritional status in Brazilian children \& adolescents. J Pediatr 2006, 82:266-72.

9. Centers for Disease Control and Prevention [http:// www.cdc.gov]

10. NHLBI: National Hearth, Lung and Blood Institute. [http:// www.nhlbi.nih.gov/guidelines/hypertension/child tbl.htm].

II. Daniels SR, Greer FR, the Committee on Nutrition: Lipid screening and cardiovascular health in childhood. Pediatrics 2008, 122: 198-208.

12. Cook S, Weitzman M, Auinger P, Nguyen M, Dietz WH, et al.: Prevalence of a metabolic syndrome phenotype in adolescents: findings from NHANES-III, 1988-1994. Arch Pediatr Adolesc Med 2003, I57:82I-7.

13. de Ferranti S, Gauvreau K, Ludwig D, Neufeld EJ, Newburger JW, Rifai N: Prevalence of the metabolic syndrome in American adolescents. Circulation 2004, I I 0:2494-7.

14. Goodman E, Daniels SR, Morrison JA, Huang B, Dolan L: Contrasting prevalence of and demographic disparities in the WHO and NCEPIATP III definitions of metabolic syndrome among adolescents. J Pediatr 2004, 145:445-5I.

15. Zimmet P, Alberti G, Kaufman F, Tajima N, Arslanian S, Wong G, Bennett P, Shaw J, Caprio S, International Diabetes Federation Task Force on Epidemiology and Prevention of Diabetes: The metabolic syndrome in children and adolescents. Lancet 2007, 369:2059-206I.

Publish with Bio Med Central and every scientist can read your work free of charge

"BioMed Central will be the most significant development for disseminating the results of biomedical research in our lifetime. "

Sir Paul Nurse, Cancer Research UK

Your research papers will be:

- available free of charge to the entire biomedical community

- peer reviewed and published immediately upon acceptance

- cited in PubMed and archived on PubMed Central

- yours - you keep the copyright
BioMedcentral 